DOI

\title{
ОСНОВНІ ХАРАКТЕРИСТИКИ ПОРУШЕНЬ РИТМУ У ПАЦІЄНТІВ З АРТЕРІАЛЬНОЮ ГІПЕРТЕНЗІЕЮ ТА ХРОНІЧНОЮ ІШЕМІЧНОЮ ХВОРОБОЮ СЕРЦЯ НА ФОНІ ГАСТРОЕЗОФАГЕАЛЬНОЇ РЕФЛЮКСНОЇ ХВОРОБИ
}

\author{
๑Д. Ю. Морєва, Л. А. Стаднюк, В. Ю. Приходько \\ Національна медична академія післядипломної освіти МОЗ України імені П. Л. Шупика
}

\begin{abstract}
РЕЗЮМЕ. Мета роботи - продемонструвати вплив ГЕРБ на перебіг ІХС на прикладі аналізу кількісних і якісних характеристик порушень ритму, а також частоти і тривалості ішемічних епізодів у пацієнтів з АГ в поєднанні 3 хронічною IXC на тлі ГЕРX. 3 цією метою було обстежено 107 пацієнтів з АГ в поєднанні з хронічною IXC, віком

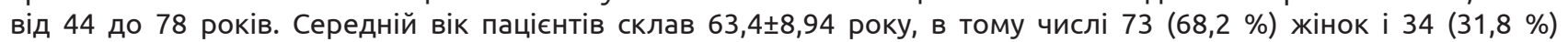
чоловіків. Основною групу склало 65 пацієнтів з АГ в поєднанні з хронічною IXC на тлі ГЕРХ і 42 пацієнти з АГ в поєднанні з хронічною IXC без супутньої ГЕРХ, відповідно, увійшло в групу контролю. Були проведені всі необхідні загальноклінічні та інструментальні обстеження відповідно до поставлених завдань дослідження: загальноклінічне дослідження, ЕхоКГ, холтерівське моніторування ЕКГ, езофагогастродуоденоскопія. Отримані дані свідчать про значно більшу частоту порушень ритму як суправентрикулярних, так і шлуночкових, в групі пацієнтів з АГ в поєднанні з хронічною IXC на тлі ГЕРХ. Крім того, за кількісними характеристиками порушень ритму пацієнти з супутньою ГЕРХ характеризувалися більш тяжким перебігом порушень ритму, що відображалося великою кількістю пацієнтів з аритміями більш високих градацій. Наявність супутньої ГЕРХ у пацієнтів з АГ в поєднанні з хронічною IXC достовірно частіше асоціювалося з наявністю ФП. Частота ішемічних епізодів у пацієнтів з АГ в поєднанні з хронічною IXC на тлі ГЕРХ була достовірно частіше в порівнянні з пацієнтами без супутньої ГЕРХ. Таким чином ГЕРБ у пацієнтів з АГ в поєднанні з хронічною IXC $€$ додатковим фактором, який погіршує перебіг IXC і створює умови для підвищення загального кардіоваскулярної ризику.

КЛЮчОВІ СЛОВА: артеріальна гіпертензія, хронічна ішемічна хвороба серця, гастроезофагеальна рефлюксна хвороба, порушення ритму, ФП.
\end{abstract}

Вступ. Демографічне постаріння населення робить дедалі актуальнішим питання коморбідності при оптимізації лікування. Хвороби системи кровообігу $є$ найпоширенішими в Україні і охоплюють 26,2 млн населення, 12,3 млн українців хворіють на АГ і більше 9 млн осіб - на IXC $[5,6]$. Найчастіше АГ поєднується з IXC.

Поряд з цим, ГЕРХ займає важливе місце серед захворювань шлунково-кишково тракту. Офіційну реєстрацію ГЕРХ в Україні розпочато лише з 2009 року; вона свідчить, що захворюваність складає 10 випадків на 1000 населення. Спираючись на дані спорадичних епідеміологічних досліджень по різних регіонах України, які головним чином проводились шляхом анкетування дорослого населення, поширеність ГЕРХ в середньому складає 30,0 \%. Щоденні скарги на печію мали 3,3 \%, щотижневі - 17,3 \% пацієнтів. Позастравохідні прояви ГЕРХ мають місце в $25 \%$ випадків, 50 \% з яких припадає саме на пацієнтів з некардіальними болями в грудній клітці $[1,2,8,12]$. За загальносвітовою статистикою, на частку неерозивної ГЕРХ (ендоскопічно негативна форма, катаральний езофагіт ендоскопічно) припадає більше 60 \% всіх випадків ГЕРХ. Ерозивний езофагіт (ендоскопічно позитивна форма, наявність ерозивних або ерозивно-виразкових дефектів слизової стравоходу) зустрічається в 37 \% від загальної кількості хворих на ГЕРX [7]. Досить активно в літературі обговорюється питання взаємозв'язку гастроезофагеального рефлюксу та виникнення пароксизмів фібриляції передсердь (ФП). Це питання оцінюється неоднозначно і потребує подальшого вивчення. Ряд досліджень показали стійкий взаємозв'язок між наявністю ГЕРХ та частотою пароксизмів ФП. Після виконання поправки на такі фактори ризику, як стать, вік, расова належність, а також на більш жорсткі предиктори розвитку фібриляції передсердь (IXC, кардіоміопатія, дефект міжпередсердної перетинки) продовжував виявлятися чіткий взаємозв'язок ГЕРХ з підвищенням ризику розвитку ФП (95\% довірчий інтервал 1,02-1,13) $[10,11,13]$. Негативний вплив патологічного гастроезофагеального рефлюксу на перебіг IXC не викликає сумніву. Рефлюкс може виступати тригерним механізмом, який ініціює виникнення нових нападів стенокардії; це демонструють результати одночасного 24-годинного рН- та ЕКГ-моніторингу, які підтверджують роль вісцеро-вісцеральних рефлексів в патогенезі рефлекторної стенокардії. Спільність іннервації стравоходу та серця пояснює подібність характеру загруднинного болю при IXС та ГЕРХ. Проведені дослідження по аналізу подібних змін у хворих з ізольованою ГЕРХ свідчать, що малі подразники від патологічно зміненого стравоходу провокують больові напади та різного роду порушення ритму $[4,9]$.

Мета дослідження - вивчити вплив ГЕРХ на перебіг IXC на прикладі аналізу кількісних та якіс- 
Огляди літератури, оригінальні дослідження, погляд на проблему

них характеристик порушень ритму та частоти і тривалості ішемічних епізодів у пацієнтів з АГ у поєднанні з хронічною IXC на фоні ГЕРX.

Матеріал і методи дослідження. Було обстежено 107 хворих на артеріальну гіпертензію у поєднанні з хронічною IXC, віком від 44 до 78 років. Середній вік хворих становив $(63,4 \pm 8,94)$ років. Жінок було 73 (68,2 \%), чоловіків - 34 (31,8 \%). Хворі були поділені на дві групи залежно від наявності супутньої ГЕРХ. В основну групу увійшли 65 пацієнтів з АГ у поєднанні з хронічною IXC на фоні ГЕРХ; контрольну групу склали 42 пацієнти з АГ у поєднанні з хронічною IXC без супутньої ГЕРХ. Обидві групи пацієнтів були зіставні за віком хворих, тривалістю і стадією АГ та тривалістю хронічної IXC.

Усім пацієнтам були проведені наступні дослідження: загальноклінічне обстеження, біохімічне дослідження крові, вимірювання АТ методом М. С. Короткова згідно з методичними рекомендаціями, ЕКГ в 12 стандартних відведеннях, ультразвукове дослідження органів черевної порожнини, ЕхоКГ, холтерівське моніторування ЕКГ, добове моніторування АТ, езофагогастродуоденоскопія.

Статистичну обробку отриманих результатів проводили за загальноприйнятими правилами з обчисленням середніх величин (М), середнього квадратичного відхилення $(\sigma)$, стандартної похибки середньої величини (m). Достовірність відмінностей визначали після перевірки характеру розподілу варіаційного ряду за t-критерієм Стьюдента, $\chi 2$-тестом. Була застосована методика інтервального аналізу порушень ритму. 3 цією метою хворі обох груп були поділені на дві підгрупи згідно з віковими інтервальними параметрами: від 41 до 60 років та понад 60 років, та на шість підгруп згідно з кількісними характеристиками порушень ритму залежно від віку, окремо для суправентрикулярних та шлуночкових порушень ритму, згідно з рекомендаціями [3]. В інтервал 1 для характеристики суправентрикулярних порушень увійшли пацієнти віком 41-60 років 3 кількістю суправентрикулярних екстрасистол за добу від 0 до 50, та пацієнти віком понад 60 років з кількістю суправентрикулярних екстрасистол за добу від 0 до 100. В інтервал 1 для характеристики шлуночкових порушень увійшли пацієнти віком 41-60 років з кількістю шлуночкових екстрасистол за добу від 0 до 50 та пацієнти віком понад 60 років з кількістю шлуночкових екстрасистол за добу від 0 до 100. В інтервал 2 для характеристики суправентрикулярних аритмій увійшли пацієнти віком 41-60 років з кількістю суправентрикулярних екстрасистол за добу від 50 до 100 та пацієнти віком понад 60 років з кількістю суправентрикулярних екстрасистол за добу від 100 до
1000. В інтервал 2 для характеристики шлуночкових аритмій увійшли пацієнти віком 41-60 років 3 кількістю шлуночкових екстрасистол за добу від 50 до 100 та пацієнти віком понад 60 років з кількістю шлуночкових екстрасистол за добу від 100 до 500. В інтервал 3 для характеристики суправентрикулярних порушень увійшли пацієнти віком 41-60 років з кількістю суправентрикулярних екстрасистол за добу більше 100 та пацієнти віком понад 60 років з кількістю суправентрикулярних екстрасистол за добу більше 1000. В інтервал 3 для характеристики шлуночкових аритмій увійшли пацієнти віком 41-60 років з кількістю шлуночкових екстрасистол за добу більше 100 та пацієнти віком понад 60 років з кількістю шлуночкових екстрасистол за добу більше 500.

Результати й обговорення. При аналізі порушень ритму в групі пацієнтів з АГ у поєднанні з хронічною IXC на фоні ГЕРХ ізольовані суправентрикулярні екстрасистоли були виявлені у 58 хворих (89,2 \% від загальної кількості пацієнтів), а у хворих контрольної групи такі аритмії траплялися суттєво $(p<0,001)$ рідше - вони зафіксовані у 22 пацієнтів (52,38 \% від загальної кількості пацієнтів групи). Середньодобова кількість суправентрикулярних екстрасистол у хворих на АГ у поєднанні з хронічною IXC на фоні ГЕРX становила $(469,86 \pm 547,31)$, що достовірно $(p<0,001)$ вище відповідного показника в групі без супутньої ГЕРХ $(77,39 \pm 128,26)$.

Хворі з шлуночковими аритміями в групі пацієнтів з АГ у поєднанні з хронічною IXC на фоні ГЕРХ виявлені у 40 осіб (61,5 \% пацієнтів основної групи), що достовірно ( $p<0,001)$ перевищувало аналогічні показники групи пацієнтів без супутньої ГЕРХ - 11 осіб (26,19 \% від загальної кількості пацієнтів контрольної групи).

Аналіз змішаних порушень ритму в обох групах пацієнтів виявив достовірно $(p<0,001)$ більшу частоту змішаних порушень ритму в групі пацієнтів з АГ у поєднанні з хронічною IXC на фоні ГЕРХ, де ці показники дорівнювали 35 (53,8 \%), тоді як у контрольній групі змішані порушення ритму зустрічались в 16,7 \% випадків.

Кількість пацієнтів з ФП в основній групі становила 13 осіб (20,0 \% пацієнтів групи) і була достовірно ( $<<0,001)$ вищою, ніж в групі без супутньої ГЕРХ, де цей показник склав 3 особи $(7,14$ \%) (табл. 1).

В результаті аналізу інтервальних показників виявлено, що в інтервалі 1 частка пацієнтів з суправентрикулярними екстрасистолами в основній групі була меншою, ніж в контрольній (відповідно 13 (22,4 \%) проти 18 (78,3 \%), р<0,0001). В інтервалі 2 частка пацієнтів основної групи з суправентрикулярними екстрасистолами 27 (46,6 \%) достовірно 
Огляди літератури, оригінальні дослідження, погляд на проблему перевищувала відповідні показники контрольної групи - 4 (17,4 \%), (р<0,01). В інтервалі 3 частка пацієнтів з суправентрикулярними порушеннями ритму в групі із супутньою ГЕРХ теж була достовірно $(p<0,01)$ вищою, ніж у групі контролю, і станови-

ла 18 (31,0 \%) проти 4 (17,4 \%) групи без супутньої ГЕРХ. Отже, інтервальний аналіз підтверджує наявність тяжчих проявів суправентрикулярної екстрасистолії у хворих на АГ у поєднанні з IXC при наявності ГЕРХ.

Таблиця 1. Характеристика порушень ритму у хворих на АГ у поєднанні з хронічною IXC на фоні ГЕРX та без супутньої ГЕРХ

\begin{tabular}{|l|c|c|}
\hline \multicolumn{1}{|c|}{ Показники } & $\begin{array}{c}\text { Пацієнти з АГ із супутньою IXС, } \\
\text { n (\%) }\end{array}$ & $\begin{array}{c}\text { Пацієнти з АГ із супутнью IXС на } \\
\text { фоні ГЕРХ, } \mathrm{n}(\%)\end{array}$ \\
\hline $\begin{array}{l}\text { Пацієнти з суправентрикулярною } \\
\text { екстрасистолією }\end{array}$ & $22(52,38 \%)$ & $40(61,5 \%)^{*}$ \\
\hline $\begin{array}{l}\text { Пацієнти зі шлуночковою } \\
\text { екстрасистолією }\end{array}$ & $11(26,19 \%)$ & $35(53,8 \%)^{*}$ \\
\hline $\begin{array}{l}\text { Пацієнти із суправентрикулярною і } \\
\text { шлуночковою екстрасистолією }\end{array}$ & $7(16,7 \%)$ & $13(20,0 \%)^{*}$ \\
\hline Пацієнти з ФП & $3(7,14 \%)$ & \\
\hline
\end{tabular}

Примітка. * - вірогідна відмінність стосовно групи контролю ( $<<0,001)$.

Не виявлено суттєвих відмінностей між групами за середньодобовою кількістю шлуночкових екстрасистол $((428,43 \pm 777,13)$ в основній групі і $(32,73 \pm 46,84)$ в контрольній, $t=1,68 ; p=0,1)$. Однак при аналізі кількісних характеристик шлуночкових порушень ритму із застосуванням методики інтервального аналізу були отримані достовірні відмінності між групами. Так, в інтервалі 1 частка пацієнтів без супутньої ГЕРХ достовірно перевищувала відповідний показник в основній групі - 10 (90,9%) проти 11 (27,5%) (р<0,0005). В інтервалі 2 достовір- ної різниці між основною групою та групою контролю отримано не було $(p=0,06)$, хоча виявлена тенденція до більших значень цього показника у основній групі - 16 (40,0%) проти 1 (9,1%) групи контролю. В інтервалі 3 частка хворих з шлуночковими порушеннями ритму в основній групі склала 13 (32,5 \%) та достовірно перевищувала аналогічні показники в групі без супутньої ГЕРХ- 0(0,0), $(p<0,05)$. Отже, інтервальний аналіз підтверджує тяжчі прояви шлуночкових аритмій у хворих на АГ у поєднанні з IXC при наявності ГЕРХ (табл. 2).

Таблиця 2. Кількісна характеристика порушень ритму залежно від віку у хворих на АГ у поєднанні з хронічною IXC на фоні ГЕРХ та без неї

\begin{tabular}{|c|c|c|c|c|}
\hline \multirow{2}{*}{$\begin{array}{c}\text { № } \\
\text { інтервалу }\end{array}$} & \multicolumn{2}{|c|}{ Суправентрикулярні екстрасистолії } & \multicolumn{2}{c|}{ Шлуночкові екстрасистолії } \\
\cline { 2 - 5 } & основна група, n= 58 & контрольна група, n=23 & основна група, n=40 & контрольна група, n=11 \\
\hline Інтервал 1 & $13(22,4 \%)^{\# \# \# \#}$ & $18(78,3 \%)$ & $11(27,5 \%)^{\# \# \#}$ & $10(90,9 \%)$ \\
\hline Інтервал 2 & $27(46,6 \%)^{\# \#}$ & $4(17,4 \%)$ & $16(40,0 \%)$ & $1(9,1 \%)$ \\
\hline Інтервал 3 & $18(31,0 \%)^{\# \#}$ & $1(4,3 \%)$ & $13(32,5 \%)$ & $0(0,0 \%)$ \\
\hline
\end{tabular}

Примітки: 1. \# - вірогідна відмінність стосовно групи контролю $(p<0,05)$;

2. \#\# - вірогідна відмінність стосовно групи контролю $(p<0,01)$;

3. \#\# - вірогідна відмінність стосовно групи контролю $(p<0,0005)$;

4. \#\#\# - вірогідна відмінність стосовно групи контролю $(p<0,0001)$.

За даними добового моніторингу ЕКГ, частка хворих на АГ у поєднанні з хронічною IXC на фоні ГЕРХ з ішемічними епізодами достовірно перевищувала відповідний показник у контрольній групі

- 23 (35,4 \%) проти 5 (11,90\%) відповідно, p<0,001. Середньодобова тривалість ішемічних епізодів у пацієнтів основної групи становила $(37,57 \pm 48,38)$, у пацієнтів групи контролю - $(8,00 \pm 3,39)$ (табл. 3).

Таблиця 3. Характеристика наявності та тривалості ішемічних епізодів у хворих на АГ у поєднанні з хронічною IXC на фоні ГЕРХ та без неї

\begin{tabular}{|c|c|c|}
\hline Група хворих & $\begin{array}{c}\text { Кількість пацієнтів з ішемічними епізодами, } \\
\text { n (\%) }\end{array}$ & $\begin{array}{c}\text { Середньодобова тривалість епізодів ішемії, } \\
\text { хв, } \mathrm{M} \pm \delta\end{array}$ \\
\hline Контрольна група & $5(11,90)$ & $8,00 \pm 3,39$ \\
\hline Основна група & $23(35,4)$ & $37,57 \pm 48,38$ \\
\hline
\end{tabular}

Примітка. - вірогідна відмінність стосовно групи контролю $(p<0,001)$. 
Висновки. Хворі на АГ у поєднанні з хронічною IXC на фоні ГЕРX продемонстрували значно більшу частоту порушень ритму як суправентрикулярних, так і шлуночкових; крім того, хворі із супутньою ГЕРХ характеризувались тяжчим перебігом екстрасистолій, що відображалося більшою часткою пацієнтів з аритміями вищих градацій. Наявність супутньої ГЕРХ у пацієнтів з АГ на фоні хронічної IXC достовірно частіше асоціювалась з наявністю ФП, ніж в групі без супутньої ГЕРХ. Частота і тривалість епізодів ішемії міокарда у пацієнтів з АГ на фоні хронічної IXC при наявності ГЕРХ була більшою. ГЕРХ виявилась додатковим фактором, який створює умови для підвищення загального кардіоваскулярного ризику у хворих на АГ у поєднанні з хронічною IXC.

\title{
ЛІТЕРАТУРА
}

1. Алексеева О. П. Коронарный синдром X - одна из внепищеводных масок гастроэзофагеальной рефлюксной болезни ? / О. П. Алексеева, И.В.Долбин // Медицина неотложных состояний. - 2009. - № 1. C. 23-25.

2. Бабак М. О. Поширеність типових та атипових проявів гастроезофагеальної рефлексної хвороби / М. О. Бабак // Український терапевтичний журнал. 2011. - № 2 - С. 33-37.

3. Жарінов О. Й. Методика виконання та інтерпретація результатів навантажувальних проб / О. Й. Жарінов, В. О. Куць, Н. В. Тхор // Здоров'я України. - 2007. № 12/1. - С. 74-75.

4. Козлова И. В. Гастоэзофагеальный рефлюкс и степень эзофагита у больных ИБС: влияние на показатели реполяризации и вариабельности сердечного ритма / И. В. Козлова, С.В.Логинов, Ю. Г. Шварц // Клиническая медицина. - 2004. - № 9. - С. 20-34.

5. Коваленко В. М. Хвороби системи кровообігу як медико-соціальна і суспільно-політична проблема: аналітично-статистичний посібник / В. М. Коваленко, В. М. Корнацький. - К. : Національний науковий центр «Інститут кардіології ім. М. Д. Стражеско», 2014. - 278 с.

6. Гастроэзофагеальная рефлюксная болезньу людей пожилого возраста / Л. Б. Лазебник, Ю. В. Васильев, А. Э. Лычкова, А. А. Машарва // Клин. геронт. - 2007. № 1. - C. 38-49.
7. Маев И. В. Гастроэзофагеальная рефлюксная болезнь - болезнь XXI века / И. В. Маев // Лечащий врач. 2004. - № 4. - С. 10-14.

8. Острогляд А. В. Перший досвід вивчення епідеміології гастроезофагеальної рефлюксної хвороби в Україні / А. В. Острогляд // Сучасна гастроентерол. 2006. - № 1. - С. 30-32.

9. Особливості клініки та спільні ланки патогенезу ішемічної хвороби серця та гастроезофагеальної рефлюксної хвороби / О. С. Хухліна, С. В. Вірста, І. В. Трефаненко // Клін. та експеримент. патологія. - 2011. - № 2. С. $151-154$.

10. Gastroesophageal Reflux Disease and Atrial Fibrillation: A Nationwide Population-Based Study / Chin-Chou H., Wan-Leong C., Jiing-Chyuan L. [et al.] // PLoS One. 2012. - Vol. 7. - P. 1932-6203.

11. Is there a link between gastroesophageal reflux disease and atrial fibrillation? / J. S. Kunz, B. Hemann, J. Edvin Atwood [et al.] // Clin. Cardiol. - 2009. - Vol. 32 (10). - P. 584-587.

12. Richter J. The refractory GERD patient / J. Richter // World Gastroenterol. News. - 2007. - Vol. 12. P. 11-13.

13. Atrial fibrillation in patients with gastroesophagel reflux disease: A comprehensive review / C. Roman, S. Bruley des Varannes, L. Muresan [et al.] // World Journal of Gastroenterology. - 2014. - Vol. 20. - P. 9592-9599.

\section{MAIN CHARACTERISTICS OF RHYTHM DISORDERS IN PATIENTS WITH HYPERTENSION COMBINED WITH CHRONIC ISCHEMIC HEART DISEASE ON THE BACKGROUND OF COMORBIDITY WITH GASTROESOPHAGEAL REFLUX DISEASE}

\author{
@ D. Yu. Morieva, L. A. Stadniuk, V. Yu. Prykhodko \\ P. Shupyk National Medical Academy of Postgraduate Education
}

SUMMARY. The aim of the study was to demonstrate the impact of GERD on during coronary heart disease as an example of analysis, quantitative and qualitative characteristics of rhythm disorders as well as the frequency and duration of ischemic episodes in patients with hypertension combined with chronic ischemic heart disease on the background of GERD. For this purpose, 107 patients were examined with hypertension combined with chronic ischemic heart disease, age 44 to 78 years. The average age of the patients was $63.4 \pm 8.94$ years, including 73 (68.2 \%) women and 34 (31.8\%) men. The main group consisted of 65 patients with hypertension combined with chronic ischemic heart disease on the background of GERD and 42 patients with hypertension combined with chronic ischemic heart disease without concomitant GERD, respectively, included in the control group. All the general clinical and instrumental examinations in accordance with the intended objectives of the study were carried out: as clinical, echocardiography, Holter ECG, esophagogastroduodenoscopy. The findings suggest that a significantly greater frequency of rhythm disorders like 
Огляди літератури, оригінальні дослідження, погляд на проблему

supraventricular and ventricular in patients with hypertension combined with chronic ischemic heart disease on the background of GERD. Also, the quantitative characteristics of arrhythmia patients with concomitant GERD is characterized by more severe rhythm disorders, that displays a large number of patients with arrhythmias higher grades. The presence of concomitant GERD in patients with hypertension combined with chronic ischemic heart disease significantly more often associated with the presence of AF. The frequency of ischemic episodes in patients with hypertension combined with chronic ischemic heart disease on the background of GERD were significantly more frequently than patients without concomitant GERD. Therefore, GERD in patients with hypertension combined with chronic ischemic heart disease is the additional factor that worsens the IHD and creates conditions to improve overall cardio-vascular risk.

KEY WORDS: hypertension, chronic ischemic heart disease, gastroesophageal reflux disease, arrhythmias, AF.

Отримано 22.06.2016 